\title{
Achievements and barriers to river school community in the conservation of the Brantas watershed
}

\author{
A. Tanjung*, A. Kodir, S. Zubaidah, M. Syaifulloh \& S.P. Yunita \\ Universitas Negeri Malang, Malang, Indonesia
}

\begin{abstract}
Pollution in the Brantas River has a serious impact on reducing its water quality. This problem raises concerns from various groups, including educational institutions. Water Quality Monitoring Community Networks, called by JKPKA is a voluntary organization consisting of schools in the Brantas and Bengawan Solo watersheds committed to preserving the river environment. This study aims to determine the achievements and obstacles of JKPKA in an effort to preserve the Brantas watershed. This study used qualitative research methods. The data collection process was carried out through interviews with the JKPKA central and regional coordinators and several high schools (SMA) teachers who played an active role in preserving the Brantas watershed. We describe the results of this study indicate that the JKPKA achievements include (1) the discovery of the Water Inquiry learning model, (2) recording the MURI record for monitoring river water quality, and (3) contributing to the improvement of the Brantas watershed environment. Meanwhile, the obstacles faced by JKPKA include (1) no support from the local Education and Culture Office, (2) the ineffective succession of management in schools and, (3) dependence on the role of teachers and students in spreading the idea of river schools.
\end{abstract}

Keywords: River school, achievements, barriers, Brantas, watershed

\section{INTRODUCTION}

The condition of the Brantas River increasingly concerns due to domestic and industrial waste pollution. One of the serious impacts arising from this pollution is a decrease in water quality as a result of population density and economic activity (Kodir 2019). About $60 \%$ of the waste polluting the Brantas River comes from households. The rest is an industrial waste of toxic and hazardous materials (Widianto 2019). The 2017 Environmental Management Quality Index (IKPLH) report shows that the water quality of the Brantas River is in the alert category, with class 3 quality being polluted (DLH Jatim 2017). These findings indicate that Brantas river water is not suitable for drinking and agriculture. However, if there are no other options, it is necessary to process these two needs. In addition, currently, the Brantas River is also known as a strategic waste disposal site with a composition of $42 \%$ diaper waste, $37 \%$ plastic, and $30 \%$ household waste (Wulandari \& Suwanda 2019).

The area most affected by waste pollution is the downstream part of the Brantas watershed, to be precise, between Mojokerto and Surabaya. Measurement of river water quality carried out by ECOTON together with the Kali Surabaya Women's Paralegal (PPKS) in April 2020 shows that the water quality of the Brantas River is getting worse towards the downstream area. Dissolved oxygen content (KOT) in seven locations including Mlirip, Wringinom, Sumengko, Karangpilang, Joyoboyo, Monkasel, and Petekan showed that the consecutive decreasing numbers from Mlirip to Petekan were $4.7 \mathrm{ppm}, 3.25 \mathrm{ppm}, 3.34 \mathrm{ppm}, 1.69 \mathrm{ppm}, 2.51 \mathrm{ppm}, 1.20 \mathrm{ppm}$. In the Mlirip

\footnotetext{
*Corresponding author: ardyanto.tanjung.fis@um.ac.id
} 
Mojokerto area, the KOT is still above the standard, namely $4.7 \mathrm{ppm}$ (the KOT standard for class 2 rivers is $4 \mathrm{ppm}$ ). In the Wringinom to Petekan area, the KOT is below the standard.

The environmental conservation efforts of the Brantas watershed are the responsibility of all parties. This principle is the background of the formation of JKPKA as a school community that cares about rivers. JKPKA was formed on June 24, 1997, in Malang as a result of a collaboration between IKIP Malang (now Universitas Negeri Malang) and Perum Jasa Tirta 1 Malang involving high school teachers along the Brantas watershed. Until 2019, JKPKA had joined 220 schools from elementary to high school levels located along the Brantas and Bengawan Solo watersheds as members. At first, JKPKA was present as a promoter of river-based learning. However, in its development, the activity program initiated by JKPKA has also contributed to the conservation efforts of the Brantas watershed. The activities include joint monitoring of river water quality, training of teachers and students on environmental education, and scientific meetings.

\section{METHODS}

This study used qualitative research methods. This research focuses on three segments of the Brantas watershed, namely the upstream, middle, and downstream parts. The data collection process was carried out through several stages, namely direct interviews, observation, and literature study. The interview process was carried out in-depth and openly using the purposive sampling technique. Some of the informants that will be interviewed are the JKPKA regional and central Coordinators. Meanwhile, a focused discussion process was conducted with several high school teachers who took an active role in preserving the Brantas watershed. The data analysis in this study used thematic analysis. This analysis was carried out through several stages (Bryman 2016). First, reviewing the interview transcripts. Afterward, coding the interview transcripts from several quotes and classifying the results of the interviews were based on the topics discussed. And the last one is to interpret findings from predetermined ideas.

\section{RESULTS AND DISCUSSION}

\subsection{JKPKA programs}

JKPKA is the driving force that coordinates schools to help conserve water resources in the Brantas and Bengawan Solo watersheds. As an organization, JKPKA has the vision to create schools that care about water resources, rivers, and the surrounding environment. Among the work programs formulated to achieve this vision are (1) teacher training, (2) student training, (3) joint monitoring of water quality, (4) Tirta Bhakti campsite and, (5) scientific meetings. The source of funding for the JKPKA work program is taken from the environmental conservation budget of Perum Jasa Tirta 1 Malang as one of the initiators and a BUMN that has responsibility and authority regarding the conservation of the Brantas watershed.

The training provided by JKPKA to teachers is varied. There is training to strengthen research, mental training, and insight into the water environment. The main objective of training for teachers is to enrich knowledge regarding river environment-based learning (Wulandari \& Suwanda 2019). All training events are carried out centrally in the tourist park owned by Perum Jasa Tirta. As a follow-up, a teacher who has attended training from JKPKA is obliged to train students in their respective schools. Training for students can be carried out through internalization in the subject matter or through student activities in the form of extracurricular activities. Suppose the existence of JKPKA has been institutionalized in the school. In that case, the student or schoolteacher representatives have the right to participate in joint monitoring of water quality, water quality camps, and scientific meetings between JKPKA members.

Joint monitoring of water quality is JKPKA's flagship work program as well as the basis for naming this community. Water quality monitoring by JKPKA applies the biotilic method by involving 
students and guidance teachers in each school going directly to the river. In its development, the consistency of this monitoring has resulted in a learning model called water inquiry. Another case with water quality monitoring, which only takes place in one day, the Tirta Bhakti Camping Activity Program (PEKERTI) is held for two days and one night. In fact, this camp is an innovation from the Saturday-Sunday (PERSAMI) camp, which is synonymous with the Boy Scout movement activity, which is now a compulsory extracurricular activity in schools at all levels. PEKERTI is designed by determining the camping location adjacent to the Brantas or Bengawan Solo rivers. Thus, campers can carry out river tracing activities and map the river environment to be evaluated and followed up in reforestation actions.

The last JKPKA program is a scientific meeting. The scientific meeting is the highlight of the JKPKA work program series. This program is a forum for creating and appreciating school students who are members of the JKPKA membership. At the scientific meeting event, there are various types of competitions such as river ambassadors, environmental essays, scientific works, etc. On the other hand, this program also intends to popularize the existence of JKPKA in the minds of students. They are the potential generation to maintain river water quality in the present and the future. Therefore, to develop environmental awareness and skills, it is necessary to know the importance of maintaining the conservation of water resources' quality. A Water Quality Monitoring Communication Network (JKPKA) was established. JKPKA is indeed not the only movement concerned with conserving water resources in Indonesia, but only JKPKA is coordinating schools around the Brantas river to conserve water resources.

\subsection{JKPKA achievements}

For 23 years contributing to preserving the Brantas watershed JKPKA has made several achievements. First, the discovery of the water inquiry learning model by Soetarno Said as the JKPKA Central Coordinator. The creation of this learning model is the fruit of JKPKA's commitment to periodically monitoring the water quality of the Brantas River. Water inquiry is actually a learning model that focuses on fulfilling students' curiosity through real learning media, namely the Brantas River. This model has been officially recognized and announced by Prof. Dr. Soeparno (UM rector for 2006-2014) in the 2014 JKPKA scientific meeting. As with other scientific learning models, the water inquiry learning model also has a learning syntax. The learning syntax of this model includes (1) forming student groups (grouping), (2) data collection (observation), (3) data analysis (analyzing), (4) group discussion (discussing) and, (5) delivering the results of the discussion (communicating).

JKPKA's second achievement was successfully holding records at the Indonesian Record Museum (MURI) concerning river water quality monitoring activities. The recording of this record took place on April 22, 2017, carried out simultaneously in two rivers, namely Brantas and Bengawan Solo, both upstream, middle, and downstream. The MURI record-breaking involved more than 1,500 students and teachers (SD, SMP, SMA, and equivalent) who were JKPKA members from Kota Batu, Malang, Blitar, Tulungagung, Kediri, Jombang, Gresik, Surabaya, Madiun, and Boyolali.

JKPKA's third achievement is to contribute to improving the environment of the Brantas River. The improvement effort is in the form of a campaign to care for the environment by students of SMAN 2 Malang (JKPKA members upstream of the Brantas River). This campaign is held regularly every week at the Car Free Day (CFD) event located in Ijen Street, Malang City and has been carried out since 2018 until now. In addition, there is environmental advocacy driven by students of SMAN 21 Surabaya. Based on the narrative of Drs. Budi Santoso M.Pd, as the coach of JKPKA SMAN 21 Surabaya, his students had reported a company dumping garbage in the Brantas River. Then the company committed acts of intimidation against his party. This happened because companies reportedly did not have an Environment Impact Assessment (EIA). To date, thanks to the reporting, they have an EIA document. 


\subsection{JKPKA barriers}

During the 23 years of the process of empowering schools in the Brantas watershed, there have also been several obstacles that have slowed down the development of JKPKA, both external and internal. JKPKA's external obstacle is the lack of significant support from the local Education and Culture Office (provincial and municipal levels). The lack of support from the Education Office has made the existence of JKPKA in school institutions very dependent on leadership policies (Fujimoto 2013). In fact, the position of school principal will continue to experience changes within a certain period, likewise, with the policy.

The second obstacle to JKPKA is the ineffective succession of management in schools. Like other voluntary organizations, the transformation of JKPKA management in schools is also prone to failure. The reason is, so far in the operational management of JKPKA there has been no structural succession planning. In fact, it is common in the teaching profession to transfer positions or places of work (schools) (Febriana et al. 2016). In addition, a single management factor also hinders the transformation process of JKPKA coaching in schools. Succession problems will arise when JKPKA supervisors enter their full term. As a result, the succession process was only based on appointment alone without any prior regeneration.

The third obstacle of JKPKA is the dependence on the role of mentor teachers and students in each school to ground the idea of schools that care about the water environment. The absence of an organizational umbrella from the Education and Culture Office has resulted in misperceptions about a water school's idea among teachers (Fujimoto 2013). Then, the assumption that the topic of river schools is only for students majoring in mathematics and natural sciences (MIPA) -especially biology at the high school level also hinders the distribution of this idea to other specializations. As a result, the dissemination of ideas born from JKPKA requires a complete commitment and a proficient communication strategy from teachers and students who have been trained in the JKPKA training program.

\section{CONCLUSION}

To sum up, JKPKA is a river school community committed to preserving the environment in the Brantas and Bengawan Solo watersheds. The JKPKA work program consists of (1) teacher training, (2) student training, (3) joint monitoring of water quality, (4) Tirta Bhakti Camp and, (5) scientific meetings. The achievements of JKPKA for 23 years of actively preserving the Brantas watershed include (1) the discovery of the Water Inquiry learning model, (2) recording the MURI record for monitoring river water quality, and (3) contributing to the improvement of the Brantas watershed environment. The obstacles experienced by JKPKA include (1) no support from the local Education and Culture Office, (2) ineffective succession of management in schools and, (3) dependence on the role of teachers and students in spreading river school ideas. The implication of our study derives from our finding on the uniqueness of the knowledge and information work carried out by JKPKA.

\section{REFERENCES}

Bryman, A. 2016. Social Research Methods. 5th ed. Oxford: Oxford University Press Inc.

Darmawan, B., Saam, Z., \& Zulkarnaini. 2010. Hubungan Pengetahuan, Sikap, Perilaku dan Peranserta dengan Kesadaran Lingkungan Hidup Serta Kesanggupan Membayar Masyarakat Sekitar Bantaran Sungai Di Kota Pekanbaru. Journal of Environmental Science, 2 (4) : 103-116. ISSN 1978-5283.

Dinas Lingkungan Hidup Jawa Timur. 2017. Dokumen informasi Kinerja Pengelolaan Lingkungan Hidup Daerah Provinsi Jawa Timur.

Ecoton.or.id. 2020. Jelang PSBB Kualitas Kali Surabaya dan Kali Mas di Bawah Baku Mutu Kelas Air. [Cited 2020 July 21]. Avaible from: http://ecoton.or.id/2020/04/24/jelang-psbb-kualitas-kali-surabaya-dan-kalimas-di-bawah-baku-mutu-kelas-air/ 
Febriana, I., Ibrohim, \& Mahanal, S. 2016. Potensi Pembelajaran Inkuiri dalam Menumbuhkan Sikap Siswa terhadap Lingkungan. Prosiding. Semnas Pend IPA Pascasarjana UM, Vol. 1, 2016, ISBN: 978-602-9286-212.https://www.menlhk.go.id/site/single_post/2611/434-sekolah-raih-penghargaan-adiwiyata-tahun-2019

Fujimoto K. 2013 Brantas River Basin Development Plan of Indonesia. In: Nissanke M., Shimomura Y. (eds) Aid as Handmaiden for the Development of Institutions. Palgrave Macmillan, London

Kodir, A. 2019. Political Ecology of a spring: People's Resistance to the Construction of a Hotel, Journal of asian sociology 48 (2), 179-198.

Neolaka, A. 2008. Kesadaran Lingkungan. Jakarta: PT. Rineka Cipta

Rosmini, D., Septiono, M A., Putri, N. E., Shabrina, H. M., Salami, I. R. S., \& Ariesyady, H. D. 2018. River Water Pollution Condition in Upper Part of Brantas River and Bengawan Solo River. IOP Conf. Series: Earth and Environmental Science 1062018 012059. https://malang.merdeka.com/kabar-malang/dua-pelajar-smadi-jatim-dinobatkan-sebagai-duta-sungai-2017-170831x.html

Sari, R. A., Prayogo, T. B., \&Yuliani, E. 2017. Studi Penentuan Status Mutu Air di Sungai Brantas Bagian Hilir Untuk Keperluan Air Baku. Brawijaya University, Engineering Faculty. Retrived April 2, 2018 from http:// pengairan.ub.ac.id/wp-content/uploads/2017/01/Studi- Penentuan-Status-Mutu-Air-DiSungai-Brantas-Bagian-Hilir-Untuk-Keperluan-Air-Baku-Rani- Anjar-Sari-125060400111052.pdf.

Wang, Q., \& Yang, Z. 2016. Industrial Water Pollution, Water Environment Treatment, and Health Risk in China. Environmental Pollution, 218: 358-365.

Widianto, Eko. 2019. Sungai Brantas Makin Memprihatinkan. [Cited 2020 July 21]. Avaible from: https://www.mongabay.co.id/2019/05/12/sungai-brantas-makin-memprihatinkan/

Wulandari, D., Suwanda, I.M. 2019. Peran Yayasan Ecoton dalam Menumbuhkan Kesadaran Ecological Citizenship Pada Masyarakat Daerah Aliran Sungai Brantas (Studi Kass Kecamatan Wringinanom Kabupaten Gresik). Kajian Moral dan Kewarganegaraan, 7(2), pp. 1008-1002. 